$G E \cup S$

Report file no.

22153

GRØNLANDS GEOLOGISKE UNDERSØGELSE

Bulletin No. 1.

\title{
ON SAPPHIRINE-BEARING ROCKS \\ IN THE VICINITY OF SUKKERTOPPEN (WEST GREENLAND)
}

BY

HANS RAMBERG

WITH 14 FIGURES IN THE TEXT

REPRINT FROM "MEDDELELSER OM GRONL.AND" BD. 142. No. 5

KØBENHAVN

BIANCO LUNOS BOGTRYKKERI

1948 
GRØNLANDS GEOLOGISKE UNDERSØGELSE BULLETIN No. 1.

\section{ON SAPPHIRINE-BEARING ROCKS IN THE VICINITY OF SUKKERTOPPEN (WEST GREENLAND)}

BY

HANS RAMBERG

WITH 14 FIGURES IN THE TEXT

KEPRINT FROM "MEDDELELSER OM GIUNLAND" BD. 142. No. 5

KØBENHAVN

BIANCO LUNOS BOGTRYKKER I

1948 


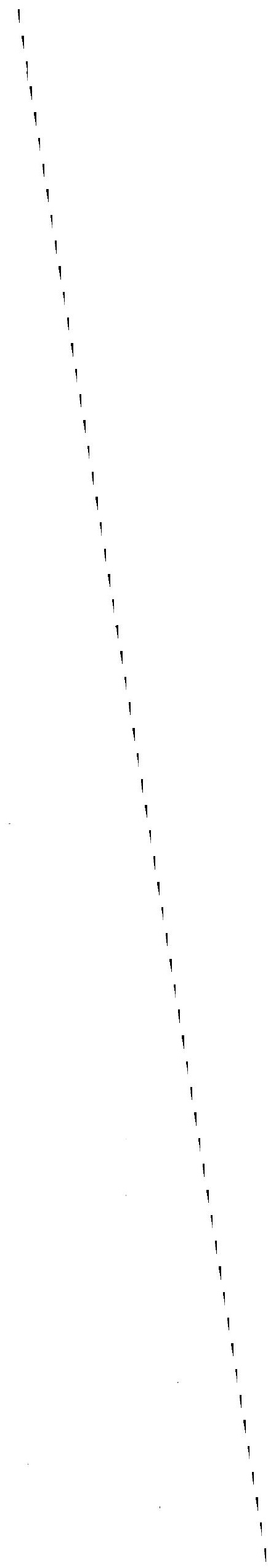




\section{CONTENTS}

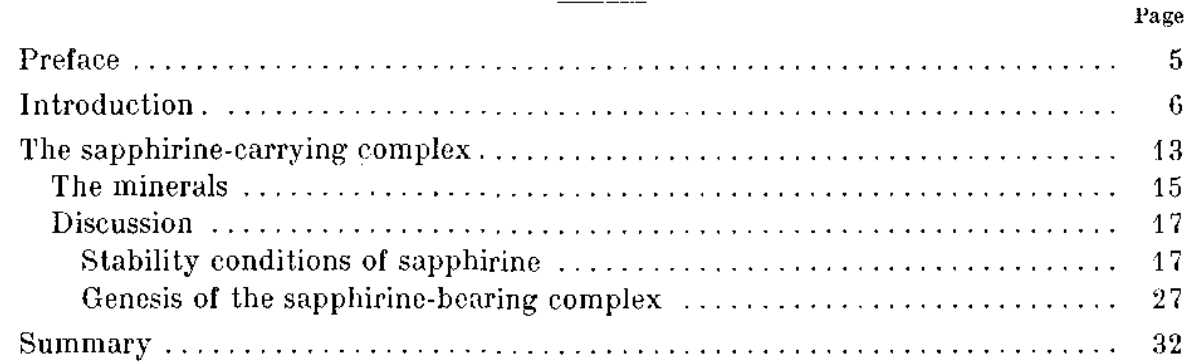




\section{PREFACE}

During the journey along the west coast of Greenland where some of the members of the G. G. U.s expeditions of 1946 had to undertake geologic investigations in the Holsteinsborg district, a scattered and casual geologic reconnaissance was made at several places along the coast. After the return to Copenhagen some rock samples from the vicinity of Sukkertoppen appeared to contain the comparatively rare nineral of sapphirine, and a brief examination of these rock specimens was made in spite of the incomplete field work. The Sukkertoppen district was actually outside the planned field of mapping of the expedition that year, and only two days were at our disposal during the stay. Due to field investigations and rock collections made by prof. A. Now-NyGaARD later in the summer (1946), observations and materials have been gathered, sufficient for a brief survey.

I am indebted to prof. NoE-NyGaARD for his friendly placing to my disposal all his notes, photos, and rock samples. Thanks are furthermore due to Miss. Eva La Cour who has drawn the figures accompanying this paper. 


\section{INTRODUCTION}

As compared with the greatly heterogencous banded and veined gneisses along the west coast of Cireenland, the granodioritic gneiss of Sukkertoppen and its proximity is rather massive and uniform. The Sukkertoppen gneiss eontains different basic inchusions, it is injected both by conformable and by discordant pegmatitic veins, and it is cut by numerous more or less frech diabase dikes. The gneiss in quostion is identical wilh other comparalively massive and homogeneous granodioritie or quartz dioritic gneisses of charnockitic affinity in the Holsteinsborg distriet, around the mouth of the long bul narrow fiord Søndre Strømfjord (Kangerdlugssuaq), and around the outpost Kangamiut.

The foliation of these complexes bccomes in some places so indistinct that they most correctly may be termed granites as is done by most of the old investigators in these fields.

The Sukkertoppen gneiss variety is coarse-grained possessing a schistose structure, and is folded round an axis dipping in southwestly direction. It contains much antiperthitic plagioclase (andesine), and quarts with Jess amounts of mierocline perthite. Biotite, hypersthene, and magnetite are the essential ferromagnesian minerals, while a dark amphibole is less common. The fresh rock is brownish grey due to the dark colored felspar and the milky quart\%. On weathered surfaces the rock recicves a brownish rusty colour obviously due to the easy decomposition of the hypersthene. It is accordingly clear that the Sukkertoppen gneiss belongs to the charnockitic gneiss types so characteristically developed in the pre-Cambrian complexes of India, Africa, Australia, and Fennoscandia. It is of particular interest that similar rocks are described from East-Greenland where they occur both in the pre-Cambrian complex ${ }^{1}$ ), and in the Caledonian migmalitic series ${ }^{2}$ ).

The inclusions consist essentially of basic rocks having parlly a lenticular and banded shape, and partly an equidimensional rounded

1) L. R. Wager: Medd. o. Gronl. 105, 2, 1939.

2) E. H. Kraxck: Medd. o. Gronl. 95, 7, 1935. 


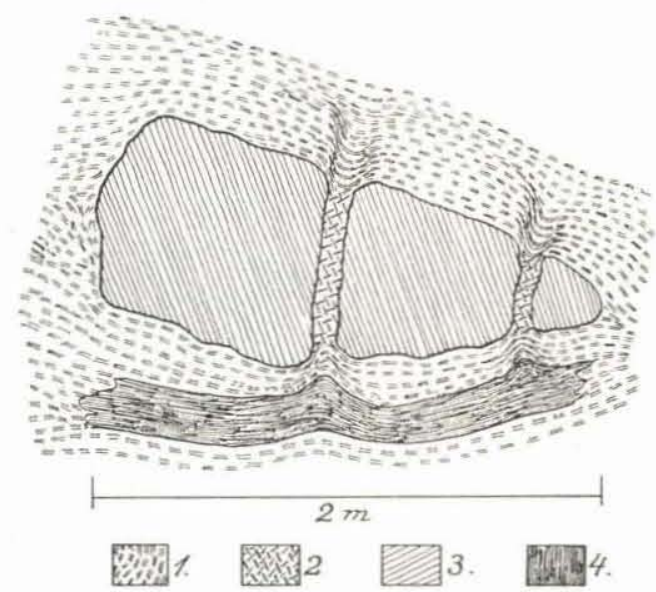

Fig. 1. "Boudins" in the Sukkertoppen gneiss. 1: granodioritic gneiss of charnockitic affibity. 2 : pegmatitic facies of the same gneiss. 3: amphibolite. 4 : fine grained hornblende schist.

or irregular shape. The inclusions are commonly gathered in stripes and bands, and one often finds that originally continuous bands undergo a gradual mechanical distortion giving rise to boudins which in turn are spread throughout the crystalline country rock as small xenolithes.

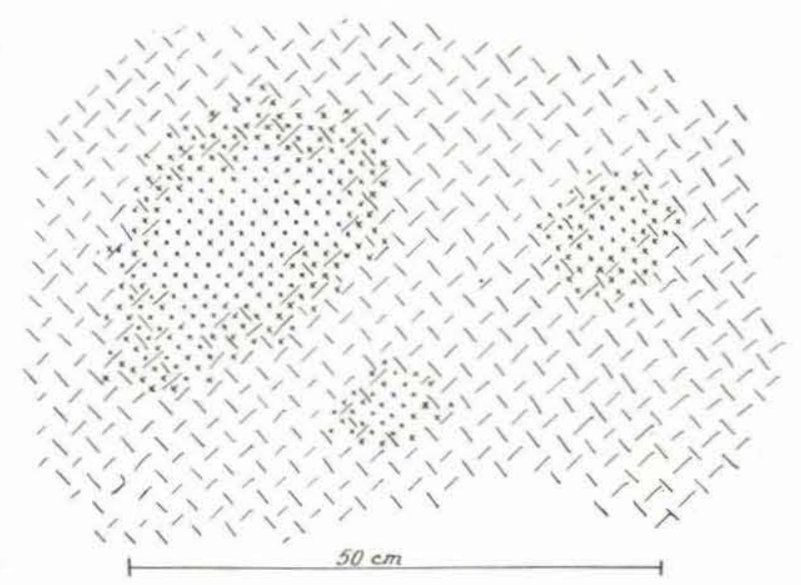

Fig. 2. Coarse-grained hornblendedioritic xenoliths in the Sukkertoppen gneiss.

The gneiss is commonly plastically foliated conformable to the surfaces of the inclusions though it now and then may "inject" itself in the form of pegmatites between the closely gathered inclusions or into fissures in them (fig. 1). Continuous transition between the granodioritic gneiss and coarse-grained hornblende-dioritic xenolithes is observed as seen on fig. 2 . 


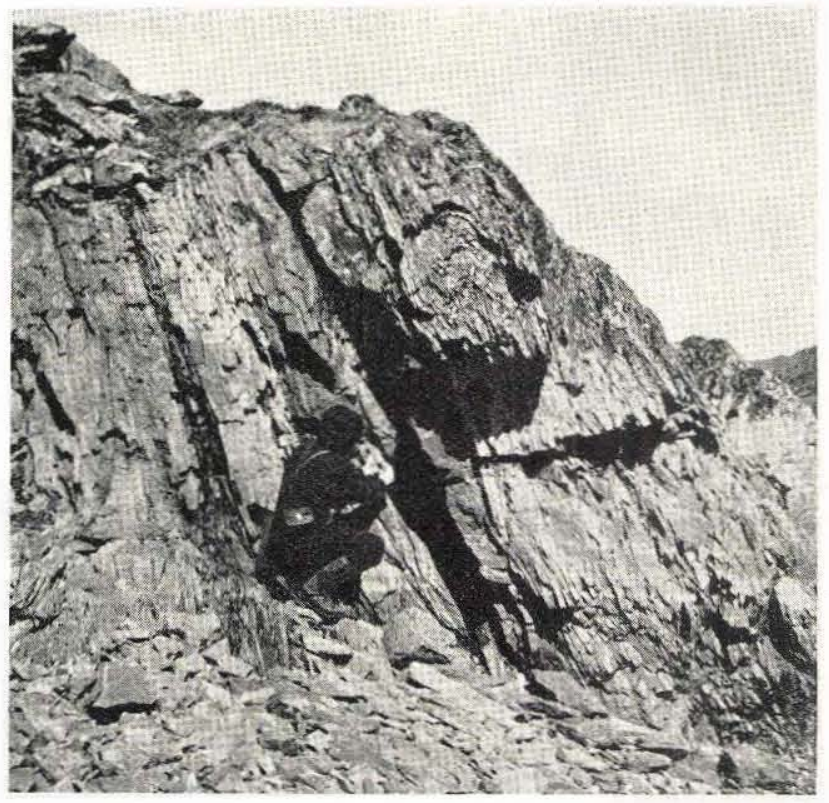

Fig. 3. Layer of phyllite and "helleflint" in banded gneiss in the vicinity of Sukkertoppen.

An endogenous reaction zone is often developed in the bacis amphibolitic xenolithes where the hornblende is either biotitized or altered to hypersthene due to emigration of $\mathrm{Si}, \mathrm{Na}$, and $\mathrm{K}$ from the surrounding granodioritic gneiss.

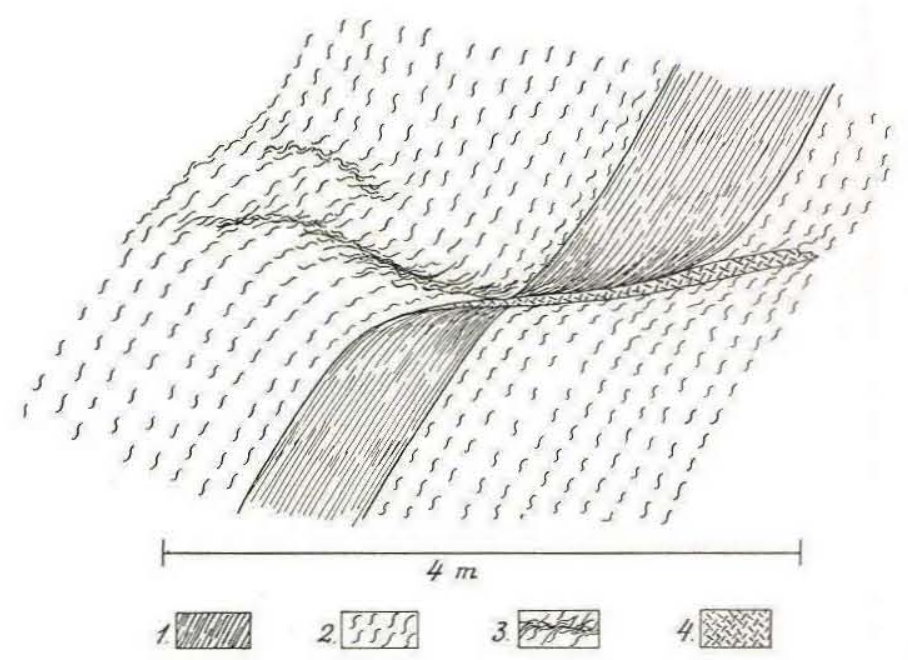

Fig. 4. Plastic and ruptural deformations in banded gneiss at Kangerdluarssuk north east of Sukkertoppen. 1: amphibolite. 2: granodioritic gneiss. 3: cataclasis, 4: pegmatite, 
The inclusions are of different types. Some are coarse-grained rather massive basic rocks containing hypersthene, hornblende and some diopsidic pyroxene with a little plagioclase and biotite. More rarely we find coarse hornblende-dioritic xenolithes in which a dark large-grained hornblende occurs. Others are more fine-grained schistose amphibolites or hypersthene-amphibolites.

These basic remnants may most reasonably be followed backwards to pyroxenites and other gabbroic magmatic rocks.

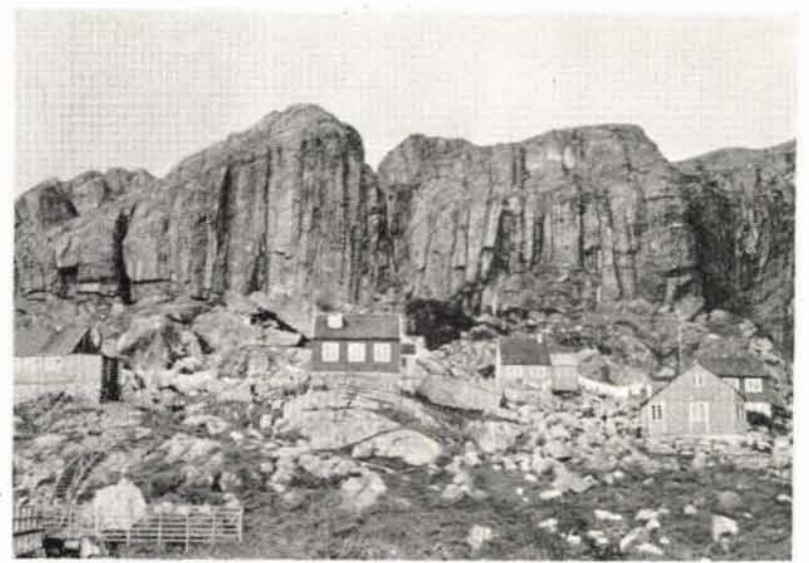

Fig. 5. Cross-cutting joints in the charnockitic gneiss of Sukkertoppen.

(NOE-NygAARD phot.).

In the immediate vicinity of Sukkertoppen no remnants of true sedimentary origin are found, while the more heterogeneous banded gneiss at the small fiord of Kangerdluarssuk east of the colony contains bands of garnet-mica schist, "helleflint", and phyllitic rocks (fig. 3).

Narrow pegmatite veins follow the foliation of the gneiss, and are now and then cutting the plane of schistosity. Some of the transverse pegmatites are characteristically confined to zones along which the gneiss has undergone a plastic-cataclastic deformation as shown in fig. 4 .

A lot of vertical diabase dikes cut the gneiss at Sukkertoppen and its vicinity. They are commonly unaltered dikes of diabasic structure traversing the gneiss mile after mile. The thickness varies from a few decimetres to some 60 metres. The diabase dikes follow an old and today indistinct fissure system in SW-NE direction. Accordingly they are often pseudo-parallel to the strike but are cutting the dip. The very distinctly developed transversal joint system (see figs. 5 and 6) is, however, very seldom filled with diabases. At some localities the transversal fissures cut the diabases.

While most of the diabases are unaltered both chemically and mechanically, a single diabase 50 metres thick situated some 3 kilometres 


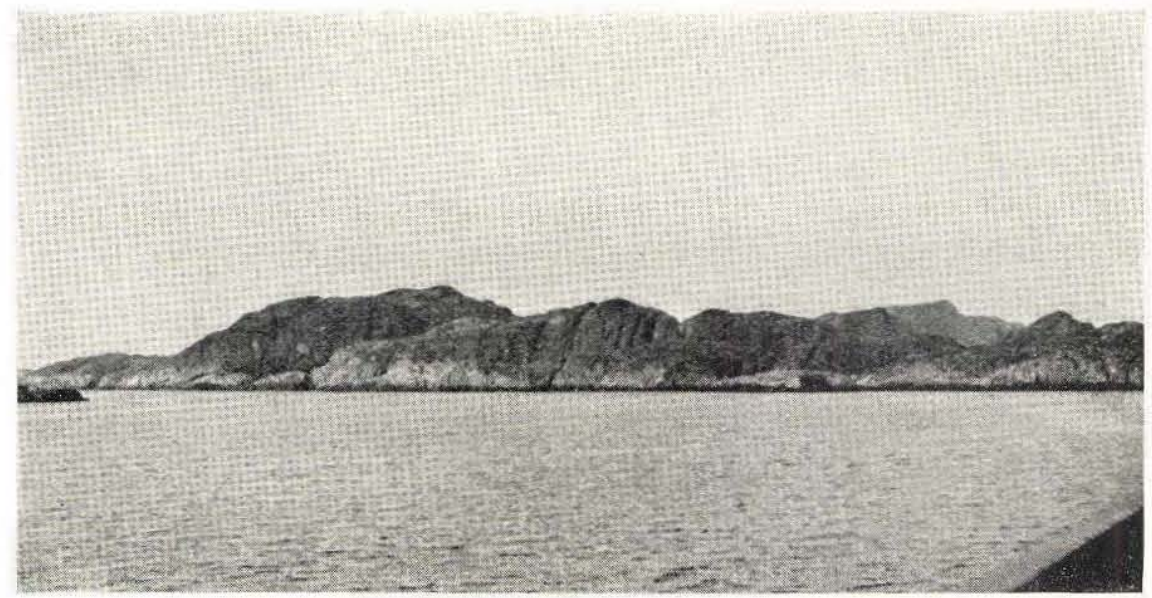

Fig.6. Cross-cutting joints in banded gneiss. Kangerdluarssuk, north east of Sukkertoppen. (H. Ramberg phot.).

NNE of the colony has been subjected to a interesting metamorphism. The central zone of this diabase dike is completely amphibolitized and foliated with occurrences of garnet, and segregation of quartz veins and aplites. The boundaries are quite unaltered (fig. 7).

The rather superficial and restricted investigations made by the writer cannot give a complete picture of the genesis of the Sukkertoppen

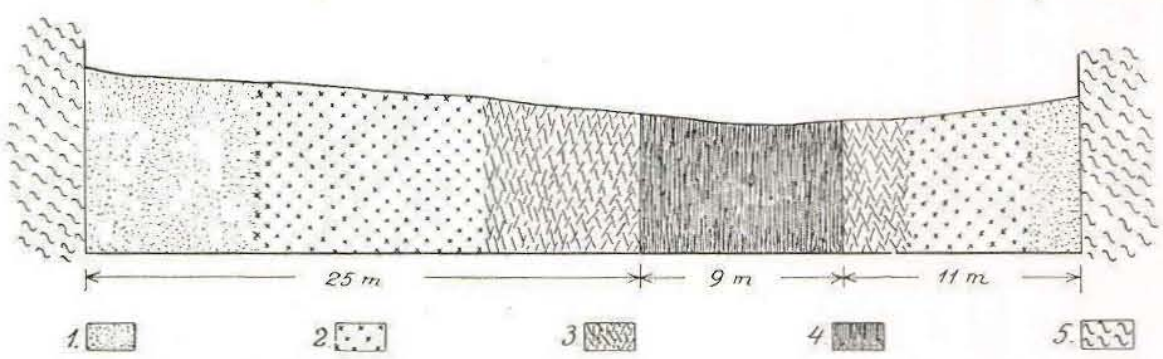

Fig. 7. Section of a partly metamorphosed diabase dike (see the text). 1: Finegrained marginal zone with ophitic texture. 2: coarse-grained hornblende gabbro. 3: schistose hornblende gabbro. 4: amphibolite with a few grains of garnet and segregations of quartz and aplite veins. 5: common granodioritic gneiss.

gneiss. This is a problem which must be solved in close connection with investigations og the old (pre-Cambrian?) orogeny of West-Greenland of which the Sukkertoppen area constitutes but a small part.

Some conclusions may however be drawn. We can for instance state that the granodioritic gneiss and the basis rocks which now occur in the form of inclusions, schlieren and remnants have together been chemically and mechanically metamorphosed as a single complex during 
the last periode of the orogeny. The deformation has taken place in solid crystalline state during which the different rocks have undergone plastic macro- and micro-creeps, cataclasm, and intermigration of their atoms, ions and molecules in harmony with their different physico-chemical characters. The structure and the mineral assemblages show that we cannot, in this case, speak about flow of a liquid granitic magma relative to the solid basic inclusions, but more correctly we may assume that all

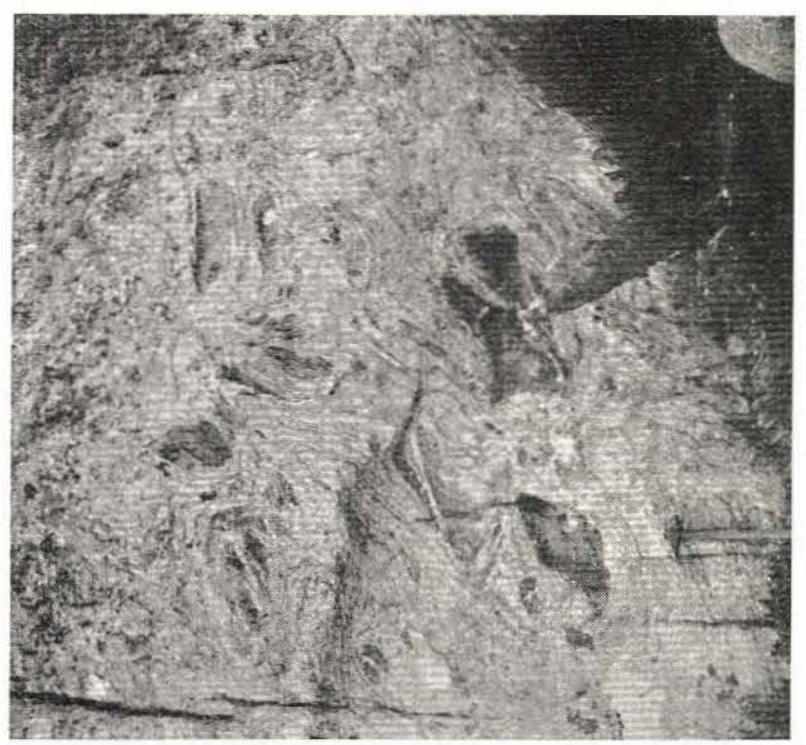

Fig. 8. Different xenolithes in the Sukkertoppen gneiss. (H. Ramberg phot.).

the rocks were solids, and that they yielded differently since they had not the same fluidity and mobility in their solid state. The mobile crystalline granodioritic components have yielded most easily under the strain forces, thus behaving as a "soft" medium in which the more sluggish and immobile basic rocks ruptured and are gradually breaked up and spread from originally continuous layers in the form of small xenolithes in the crystalline gneiss.

Due to the mobility of the elements of the salic minerals (quartz, felspars) these elements will migrate comparatively easily through the solid rocks consolidating themselves as granitic minerals at suitalbe places, e. g. fissures. In 'this way the pegmatitic veins are explained as the finishing product of the metamorphic interaction of the crystalline rocks.

Diabase dikes have been intruded after the orogenic deformation. Only a single dike (fig. 7) has been able to register the last mechanical motion in the field. 
It is probable that the basio schlieren and inclusions are remnants of dikes, plugs or sills which in their turn have been intruded into the substraturn which now is regenerated as the charnockitic granodioritic gneiss.

An important question to solve is whether or not the gneiss has changed its chemical composition during the metamorphic deformation. Prior to the dynamothermal alteration considered above, the granodioritic gneiss may have been of granodioritic character so that the metamorphism has not necessarily been accompanied by any important conveyance of matter. A granitization with conveyance of granitic substances in the one or the other manner is of course possible. But if the granodioritic component of the gneiss is formed metasomatically of old non-granitic rocks it does not seem reasonable that the greatest quantities of the substances convoyed have been supplicd during that period of the deformation which has given birth to the present structure of the area. The great areas with rather homogenous granodioritic gneiss in combination with the distinctly confined inclusions into which the granitic motasomatism has reached only small extensions of the order of centimetres or decimetres impeach a thoroughly granitization during' the later periods of the orogeny. At the present step of investigation it is impossible to decido whether or not the gneiss has received its present granodioritic composition by the help of a slow conveyance of migration elements (e. g. $\mathrm{K}, \mathrm{Si}, \mathrm{Na}, \mathrm{Al}$, ete.) during periods reaching backwards till long before the last dynamothermal deformation.

The metamorphism of the central parts of the one diabase (fig. 7) is not casy to understand. The central amphibolite with small garnet grains, and quartz and aplite veins is entirely of regional metamorphic character. In spite of its regional character the alteration is confined to the central zone of the dike, and even the granodioritic country rock has not been subjected to a visible plastic deformation conformable to the foliation in the central amphibolite. The gneiss must have been rigid and resistant during the plastic deformation of the central zone of the diabase, and the gneiss has acted as the jaws of a vice ("screwspanner") which have pressed the yieIding central diabase together. The difference between the primary structure of the central and marginal zones of the diabase, and an occurrence of more mobile olements and minerals in the central part is a possible reason for the greater fluidity of the central zone during the deformation. The mechanical deformations with their micro-creep of minerals may in turn have catalyzed the recrystallization of the central zone in the amphibolite facies. 


\section{THE SAPPHIRINE-CARRYING COMPLEX}

After the previous brief introduction we shall deal in some detail with the sapphirine-bearing complex. The complex occurs as a rather great collection of inclusions in the Sukkertoppen gneiss about $3-4 \mathrm{~km}$ north of the Sukkertoppen colony where it is situated at a small bay. The light green hornblende which occupies most of the inclusions distinguishes this included complex from most of the xenolithes previously mentioned. The complex appears as a long vertical lens some hundred metres thick extending some kilometres in north easterly direction from the small bay.

The inclusion is very heterogeneous with a light green rock essentially consisting of a common emerald-green hornblende occurring in large lenticular bodies surrounded by white plagioclase-rich rocks. The whole complex has obviously been subjected to an intense plastic deformation along with the enclosing granodiorite at the same time as a metamorphic differentiation has heterogenized the inclusion.

This sapphirine-carrying complex may perhaps best be characterized by saying that it consists of lenses and bands of varying amounts of the principal minerals: common green hornblende, plagioclace, bronzite, spinel, sapphirine, phlogopite, and olivine.

In some schlieren these minerals occur comparatively uniformly scattered, though as a rule a few of them congregate in certain bands. The greater part of the complex consists of hornblende-rich rocks containing hornblende in grains of 2-3 milimetres, a dark green spineloften developed in large porphyroblasts--, a few small grains of sapphirine, some basic plagioclase, and some bronzite.

The plagioclase may also constitute comparatively monomineralic bands and lenses accompanied by small amounts of bronzite, hornblende, spinel, and sapphirine, and/or phlogopite. The bronzite may, sometimes occur in the form of monomineralic narrow bands, a few centimetres thick.

However, the complex is perhaps best visualized by help of a description of specimens of the different varieties. 
Specimen (1) is an intensively foliated rock of which a white plagioclase oceupies the greater part, occurring as a type of sugar-grained ground-mass of grains up to $2 \mathrm{~mm}$. In this ground-mass small parallel lenticular assemblages of nut-brown bronzite are situated, occupying about 20 per cent. of the rock. The lenses are some $1-2 \mathrm{~cm}$ long, and $2-4 \mathrm{~mm}$ thick. Comparatively few grains of hornblende occur distributed as single small grains or segregated into small lenses.

Specimen (2) contains more hornblende and bronzite than (1). Small schlieren of hornblende and bronzite alternate with bands of sugar-grained white plagioclase. Some of the bronzite schlieren contain very small grains of sapphirine, others contain some spinel. The plagioclase constitutes some $50 \%$, bronzite about $30-35 \%$, and homblende the rest.

In specimen (3) bronzite and hornblende are substituted by phlogopite simultaneously as the structure becomes more schistose.

Specimen (4) is a sample of the common green amphibolite bands with emerald-green hornblende as the most essential mineral. Spinel and sapphirine occur comparatively richly at some places in this rock type.

(5) is a sample of the bronzite rocks which contain grains of spinel and sapphirine, the lattor often constituting the mantle and the former, the kernel in "armed" relicts.

(6) This specimen shows headsize porphyroblasts of a dark bluegreen spinel situated in a hornblende rock, and being surrounded by a mantle of plagioclase, and great flakes of phlogopite (fig. 9).

Speeimen (7) is a rather rare variety in this complex. It shows a rock consisting of light yellowish-green olivine, and nut-brown bronzite with small lenses of emerald-green hornblende and spinel. Sapphirine is not found in this olivine-bearing band though the mineral occurs in the other types examined.

As type (8) may be mentioned rocks intermediate betwcen the plagioclase-hornblende-rich included complex and the granodioritic country rock.

(9) At last small veins and dikes of quartz and plagioclase pegmatites may be mentioned. When intercepting the complex the quartz veins are accompanied by an exogenous reaction zone in which hornblende etc. are altered into diopside, bronzite, labradorite, and some flakes of biotite. The pegmatites consist of acid labradorite, bronzite or hypersthene, and a fow flakes of biotite. 


\section{The minerals.}

(a) Plagioclase is macroscopically a comparatively clear, on weathered surfaces white, variety occurring in grains of $1-3$ milimetres. Albite and pericline twinning lamellae are common. The composition appears to be rather constant in the different rock schlieren, viz. some $\mathrm{An}_{90}$ measured by the refringence $\gamma: 1,582 \pm$.

The mineral occurs partly as a sugar-grained ground-mass in which the other minerals are included, partly as single or glomeroporphyroblastic grains dispersed in the hornblende-rich rocks. Of some interest is its occurrence as a $1-2$ milimetres thick mantle round the spinel porphyroblasts which are so abundant in the amphibolite schlieren. Here phlogopite also accompanies the plagioclase mantle. Now and then the plagioclase may penetrate the spinel porphyroblasts in a kelyphitic manner.

The plagioclase in the reaction zones along the quartz veins is more acid, lying intermediate between andesine and labradorite. The darkcolored plagioclase of the pegmatite veins themselves is also basic andesine $\left(\mathrm{An}_{45}\right)$.

(b) Hornblende, together with plagioclase, is the most abundant mineral constituting partly comparatively monomineralic rock bodies where smaller amounts of spinel, sapphirine etc. occur. In other bands hornblende grains are scattered throughout. The mineral is light emeraldgreen of colour exhibiting a good cleavage. In powder under the microscope it shows a distinct pleocroism, it has a large negative optical angle, and its optical refringence is: $\beta \sim 1,638 . \mathrm{c} / \gamma$ approaches $21^{\circ} . \alpha$ : light yellow, $\beta$ : yellowish green, $\gamma$ : bluish green.

The hornblende is thus apparently a rather aluminous common metamorphic amphibole. The low index of refraction shows, in combination with the light colour, that it is high in $\mathrm{Mg}$ and low in iron.

(c) As mentioned previously the bronzite develops comparatively pure schlieren, or it may be a less abundant constituent of the hornblende rock, the plagioclase rock, and the olivine-bearing band. It is a nut-brown orthorhombic pyroxene with a faint pleocroism: $\alpha$ : light pink, $\gamma$ : clear. (一) $2 \mathrm{~V}$ about $90^{\circ} . \alpha(\mathrm{Na}): 1,674, \gamma(\mathrm{Na}): 1,682$. These optical data correspond to some 15 mol. per cent. $\mathrm{FeSiO}_{3}$.

The large grains of orthorhombic pyroxene scattered in the pegmatite veins in the complex appears to be a dark hypersthene: $\alpha$ : pink 1,693, $\gamma$ : green. The optical angle is negative. Thus its composition may approach some 27 mol. per cent. $\mathrm{FeSiO}_{3}$.

(d) The spinel is a dark sea-green ceylonite which is developed partly as headsize porphyroblasts with traces of crystal faces, partly as small grains in the hornblendite, the bronzite schlieren, and in the olivine- 
bearing band. As a rule the spinel is somewhat altered into sapphirine, and these two minerals are always intimately associated. In thick fragments under the microscope it looks opaque, while thin fragments are transparent and sea-green. $\mathrm{n}(\mathrm{Na}) \sim 1,740$.

Wo have every reason to assume that, in the paragenesis examined, the spinel is a mixture of pure $\mathrm{Mg}$-spinel, and hercynite $\left(\mathrm{FeAl}_{2} \mathrm{O}_{4}\right)$. (The spinel from Fiskenæsset, p. 18, is, according to J. LORENzeN ${ }^{1}$ ), also a pure ( $\mathrm{Mg}, \mathrm{Fc}) \mathrm{Al}_{2} \mathrm{O}_{4}$-type). The refringence of this is determined by the present writer to $1,7273 \pm(\mathrm{Na})$. The Fiskenæsset occurrence is analogue to the Sukkertoppen rocks.

But in the latter the $\mathrm{Fe} / \mathrm{Mg}$ ratio in all minerals is higher than in the Fiskenæsset minerals. An interpolation between pure $\mathrm{Mg}$-spinel and hercynite indicates that the $\mathrm{Mg} / \mathrm{F}_{\mathrm{c}}$ ratio of the present spinel corresponds to about $6 / 4$ according to the refringence. ${ }^{2}$ )

(e) Phlogopite occurs in the schistose plagioclase gneiss, and in the shape of large scales around the large spinel porphyroblasts.

It is a light-brown variety partly altered (weathered?) into a silvercoloured product. The pleocroism is distinct. The negative optical angle is small. $\gamma \sim \beta \sim 1,595$.

According to Winchell op. cit. these data correspond to a very Mg-rich mica with a Mg-silicate/Fe-silicate-ratio approximating 85/15.

(f) The sapphirine is a light-blue mineral (the colour is darker than that of the Fiskenæsset variety, but lighter than that of the Avisisarfik type) always closely associated with spinel, in most of the rock-varieties. In the olivine-bearing bands, however, no sapphirine is found in spite of the abundance of spinel here. In the pure bronzite bands one may find large sapphirine grains without spinel in the immediate surroundings. In other places in the same rock, however, sapphirine occurs as reaction rims around the spinel.

The sapphirine develops very seldom as idiomorphic grains.

In powder under the microscope it shows an intense pleocroism, and a very distinct dispersion about the large negative optical angle. The following optical data were determined:

$$
\begin{aligned}
& \alpha=\text { (Na) } 1,714+-0,001 \text { clear colour less. } \\
& \beta=\text { clear blue } \quad \mathrm{v} \gg \mathrm{r}, 2 \mathrm{~V} \text { negative. } \\
& \gamma=\text { (Na) 1,7195 + }-0,001 \text { clear blue. }
\end{aligned}
$$

According to structural and chemical investigations sapphirine is a mixed crystal in which $\mathrm{Mg}$ and $\mathrm{Fe}$ are mutually substitutable to a

1) Medd. o. Grønl. VII, 1893, p. 19.

2) A. N. Wivchell: Elements of optical Mineralogy. N.Y. 1945. 
considerable extent. The $\mathrm{Si}-\mathrm{Al}$ substitution is probably very moderate. Its formula is written:

$$
\left.(\mathrm{Mg}, \mathrm{Fe}, \mathrm{Al})_{2} \mathrm{Al}_{4}(\mathrm{Si}, \mathrm{Al}) \mathrm{O}_{10}{ }^{\mathrm{l}}\right)
$$

When comparing the refringences of the Sukkertoppen sapphirine with other analyzed sapphirines ${ }^{2}$ ) we may conclude that the $\mathrm{Mg} / \mathrm{Fe}$ ratio of the present sapphirine approaches 91/9.

(g) Diopsidic pyroxene is found, acossiated with hypersthene, plagioclase $\left(A n_{45}\right)$, and biotite as reaction product between the amphibolite and small cross-cutting quartz veins.

(h) Olivine occurs as mentioned in schlieren consisting of olivine, bronzite, some hornblende, and spinel. Macroscopically the olivine is a light yellowish green variety. Under the microscope it is clear and homogeneous.

$$
\gamma=1,684(\mathrm{Na}), 2 \mathrm{~V} \text { about } 90^{\circ}
$$

which according to WINCHELL indicates a type rich in Mg with $92 \mathrm{~mol}$. per cent. forsterite.

\section{Discussion.}

In this section we shall deal with:

(1) The metamorphic facies, i. e. the $\mathrm{P}, \mathrm{T}$ conditions at which the complex is recrystallized, and the stability relations of the minirals.

(2) The genesis of the Sukkertoppen sapphirine-bearing rocks.

\section{Stability conditions of sapphirine.}

From the view-point of metamorphic facies of rocks the comparatively rare sapphirine-carrying parageneses are of considerable interest. Due to the great difficulties connected with syntheses of metamorphic minerals the petrologist has to gather data of interest to the stability conditions of minerals during his investigation of the natural rocks. Now, since 3 of the 7 known sapphirine-occurrences of the world are situated at the West coast of Greenland, the stability relations and mode of occurrence of sapphirine may also be of general importance for the understanding of the somewhat peculiar metamorphism which has affected the gneisses of the West Greenland orogeny (orogenesis).

1) R. T. Pridir: Geol. Mag. Vol. I.XXXII, 1945, p. 50.

2) See the references on pp. 18--19. 
The seven sapphirine occurrences referred to in literature have the following parageneses:

(1) Fiskenæsset, West Greenland $\left.{ }^{1}\right)$.

a) Sapphirine, phlogopite, gedrite, monoclinic hornblende (pargasite), cordierite, kornerupine, anorthite.

b) Sapphirine, bronzite, spinel.

(2) Avisisarfik, Godthaab district, West Greenland 2). Sapphirine, gedrite, corundum, phlogopite, spinel.

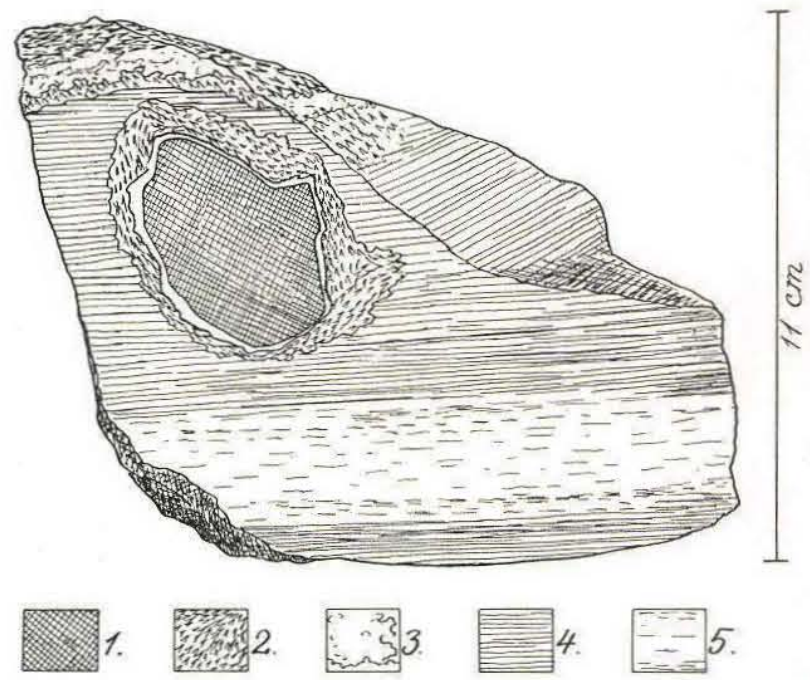

Fig. 9. Spinel porphyroblast hornblende rock of the sapphirine-bearing complex. 1: spinel with some sapphirine. 2 : phlogopite. 3 : bytownite (the white mantle round the spinel porphyroblast consists also of bytownite). 4: hornblende rock. 5: bronzite-rich band.

(3) Sukkertoppen, West Greenland.

Sapphirine, common hornblende, bronzite, bytownite, spinel, phlogopite, (Olivine and diopside are not found assiocated with sapphirine, see pp. 14-17).

(4) Dangin, West Australia ${ }^{3}$ ).

Sapphirine, biotite, microcline.

(5) St. Urbain, Quebec, Canada ${ }^{4}$ ).

Sapphirine, plagioclase, biotite, spinel, rutile, ilmenitie.

1) N. V. Ussing: Z. Krist. XV 1889, p. 600; O, B. Bøggild: Medd. o. Grønl. 32,1905 , p. 222 .

${ }^{2}$ O. B. BøgGILD, op. cit. p. 400 and personal communications.

3) R. T. Prider, op. cit.

4) Ch. H. Warren, Am. Jour. Sci. CLXXXIII 1912, p. 263. 
(6) Madagascarl).

Sapphirine, anorthite.

(7) Vizagapatam, India ${ }^{2}$.

Sapphirine, spinel, hypersthene, biotite, (sillimanite?) (According to LAGrorx, op. cit. p. 82, the existence of sillimanite in this paragenesis is uncertain).

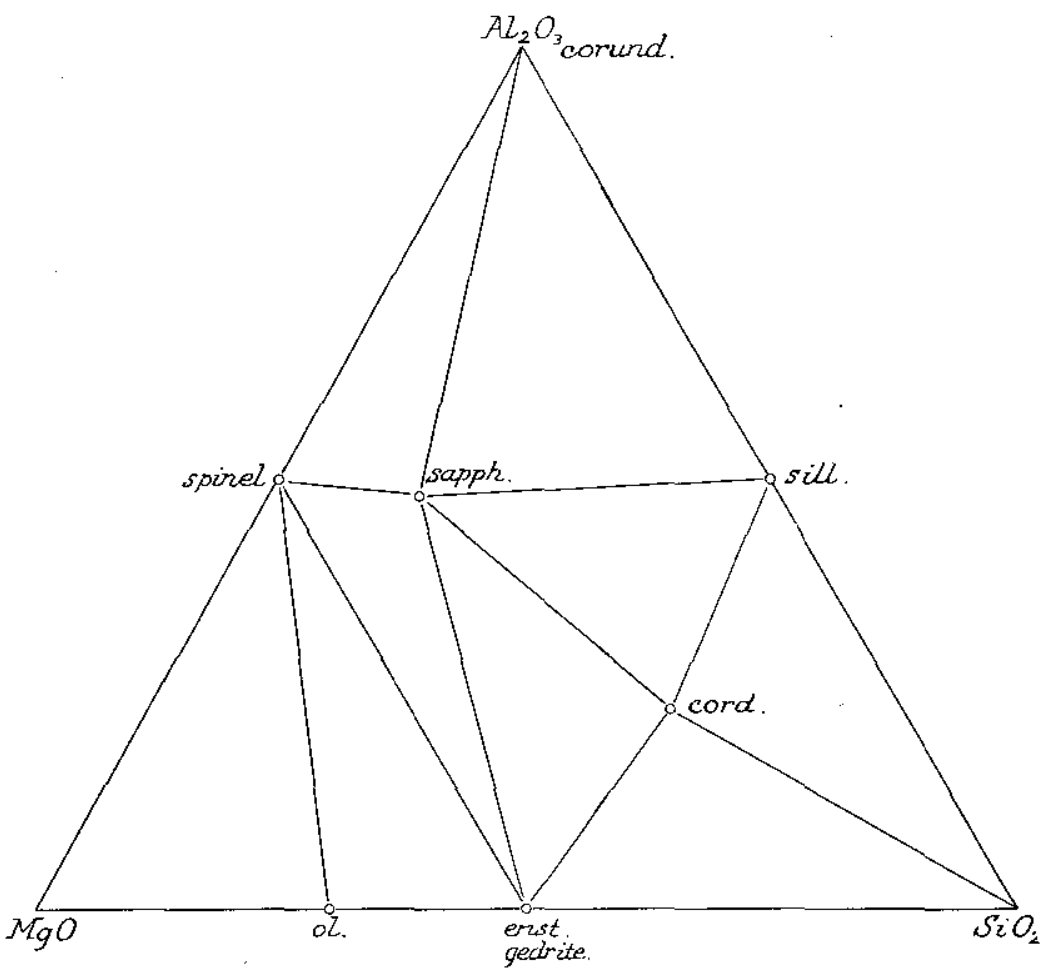

Fig. 10. Mg, Si, Al- diagram of sapphirine-bearing rocks (see also the text).

Placed in a Si, Al, Mg-diagram these parageneses correspond to fig. 10. Common hornblende and plagioclase will appear when $\mathrm{Na}$ and $\mathrm{Ca}$ are introduced; phlogopite, biotite, and microcline appear when $\mathrm{K}$ is introduced; kornerupine demands $\mathrm{B}_{2} \mathrm{O}_{3}$, and rutile and ilmenite demand $\mathrm{TiO}_{2}$.

Fig. 11 is a $\mathrm{CaO}, \mathrm{SiO}_{2}, \mathrm{Al}_{2} \mathrm{O}_{3}, \mathrm{MgO}$ tetrahedon diagram. From the Sukkertoppen sapphirine-occurrence the following minerals may be introduced in diagram fig. 11: h'bl., bronzite, bytownite, spinel, and sapphirine. Thus 4 components give rise to 5 minerals. This seeming disagreement with the phace law may be due to instability as discussed

1) M. A. Lagroix, Bull. Soc. Franc. Min. 52, 1929, p. 76.

2) T. L. Walker, W. H. Collins, Geol. Surv. India. XXXVI, p. 1. 
on p. 30 , or it may be due to the $\mathrm{H}_{2} \mathrm{O}$-tension, the small $\mathrm{Na}$ contents in the basic plagioclase (and the common hornblende), or an incomplete $\mathrm{Fe}-\mathrm{Mg}$ isomorphism in the different ferromagnesian minerals. On account of the albite contents of plagioclase this mineral may exist in stable equilibrium with four other minerals, e.g. spinel, bronzite, sapphirine, and hornblende (see diagram). Due to different affinity to $\mathrm{Mg}$ and $\mathrm{Fe}$ in e. g. spinel and sapphirine (see pp. 15,17), spinel will exist in true equilil)rium with the four minerals of the tetrahedon: en., an., h'bl., sapph.

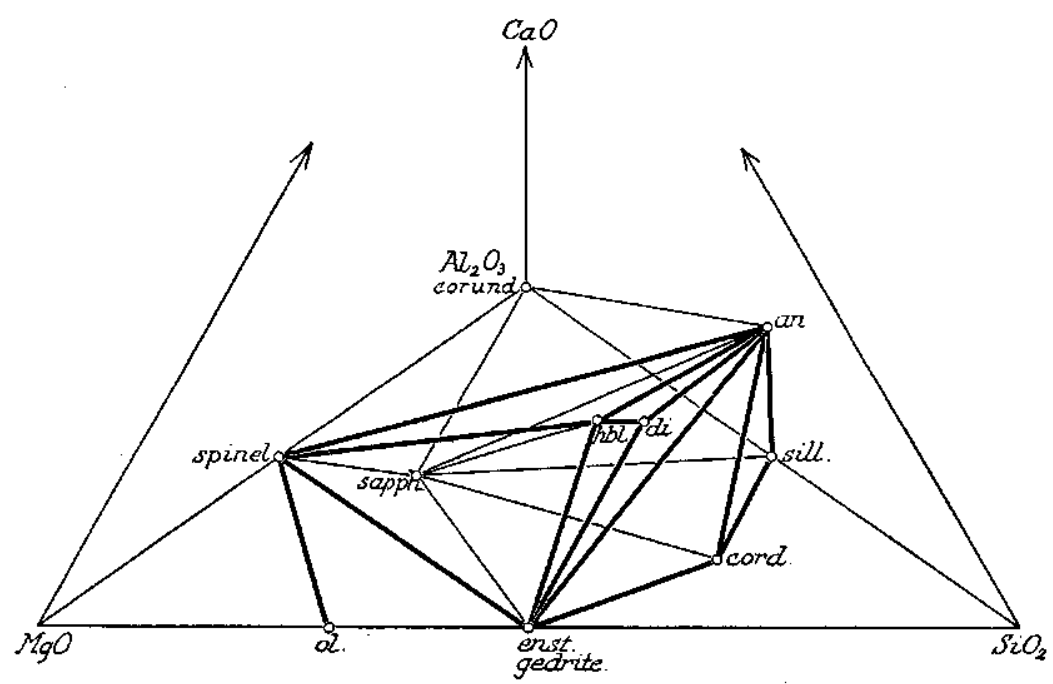

Fig. 11. Mg, Si, Al, Ca-diagram of sapphirine-bearing rocks. As may be seen the following parageneses are possible at stable conditions 1) en (gedrile), an, $h$ 'bl, di. 2) en, cord, an, sapph. 3) en, an, sapph, h'bl. 4) en, h'bl, sapph, spinel. 5) h'bl, an, sapph, spinel. 6) sapph, an, sill, cord. 7) an, sill, sapph, corund. 8j an, sapph, spinel, corund.

These parageneses are worth a more detailed discussion. It is for instance interesting that olivine never is found together with sapphirine in spite of the occurrence of olivine in the sapphirine-bearing complex at Sukkertoppen. This experience coincides very well with the diagram fig. 10 where sapphirine is separated from olivine by the line: enstatite (gedrite)-spinel. Now, since the sillimanite of the Indian paragenesis is uncertain, and the Avisisarfik paragenesis represents instability (sapphirine occurs here as a reaction mantle around gedrite where this mineral borders the corundum and spinel), we may conclude that the hitherto known sapphirine-parageneses harmonize quite well with the equilibrium diagrams figs. 10 and 11.

The diagrams 10 and 11 show that sapphirine will appear in rocks with considerable chemical variations, i. e. its chemical stability field is 
rather large. The fact that sapphirine is a very rare mineral therefore indicates that it is stable inside a rather narrow $\mathrm{P}$, T-field. If sapphirine had a large stability $\mathrm{P}$, T-field this mineral would have appeared in common spinel-carrying rocks, and in the distributed cordierite, anthophyllite, sillimanite (quartz-free) gneissses so commonly encountered in highly metamorphic areas.

When the sapphirine-bearing rocks are to be placed in the common metamorphic facies series of rocks it is of particular interest that both

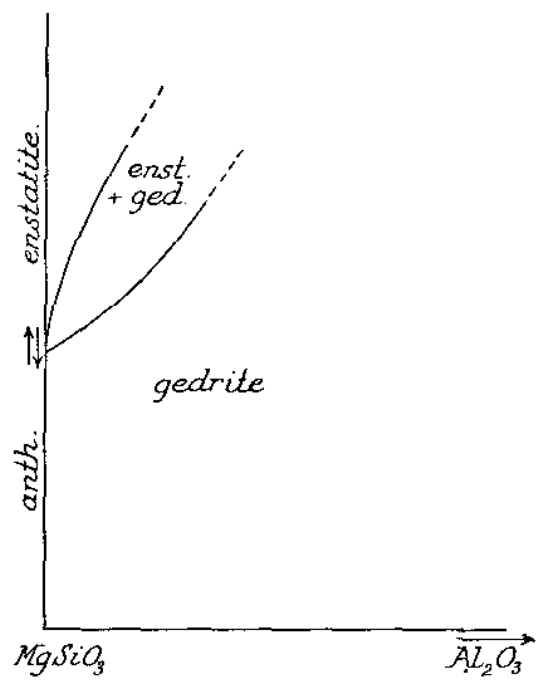

Fig. 12. Theoretical diagram showing the equilibrium conditions of the acossiation: orthorhombic pyroxene - alumininous orthorhombic hornblende (gedrite).

bronzite and gedrite occur in sapphirine parageneses, and that aluminous common hornblende also is stable at these $\mathrm{P}, \mathrm{T}$-conditions. Bronzite indicates a degree of metamorphism corresponding to granulite facies ${ }^{1}$ ) (the typical contact facies: pyroxene-hornfels facies is impossible in these circumstances), while both gedrite and common hornblende are index-minerals of the lower amphibolite facies.

Diagram fig. 12 shows, however, that gedrite (aluminous anthophyllite) may be stable at the same $\mathrm{P}$, T-conditions as hypersthene (enstatite) is stable. It is also clear that some varieties of common hornblende are stable at the same $P, T$-conditions at which bronzite occurs (see below).

From these considerations we can conclude that the physical stability field of sapphirine is confined to a narrow $\mathrm{P}$, $\mathrm{T}$ -

1) P. Eskola in: Barth, Correns, Eskola: Die Entstehung der Gesteine, Berlin 1939. 
field situated between granulite facies and amphibolite facies.

The metamorphic facies represented by the gneiss and its inclusions in the vicinity of Sukkertoppen is somewhat peculiar since bronzite and common hornblende are in stable equilibrium. Such combinations, which are now and then found in highly metamorphic areas ${ }^{1}$, have not

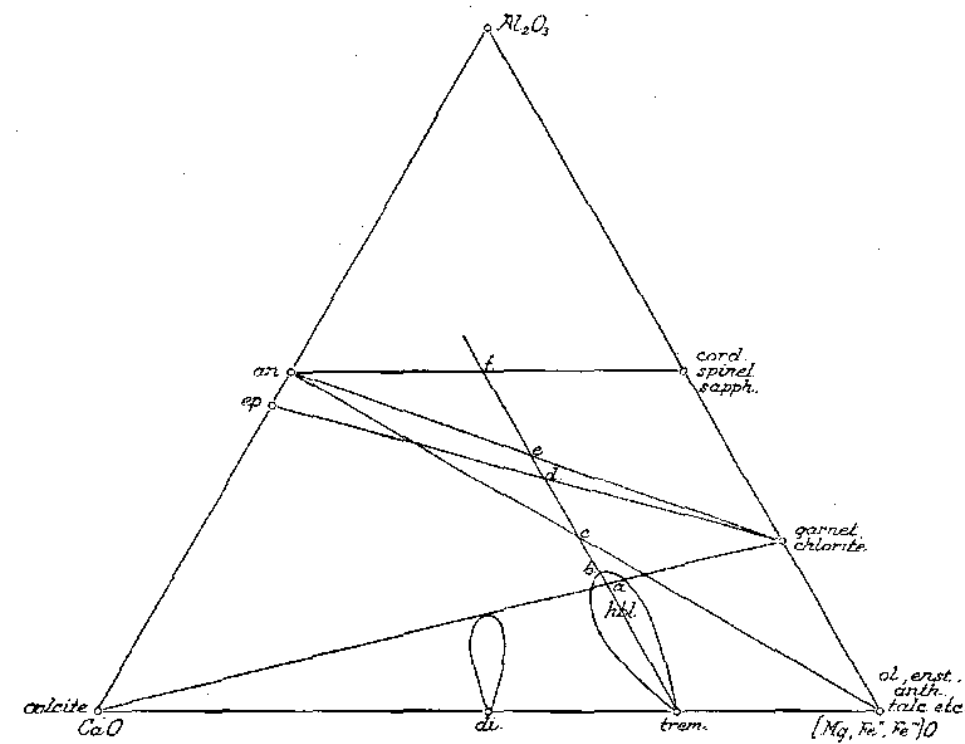

Fig. 13. $\mathrm{Al}, \mathrm{Ca},(\mathrm{Mg}, \mathrm{Fe} . \mathrm{Fe}$...)-diagram of hornblende-bcaring rocks (see also diagram fig. 14) $a, b, c, d, e, f$ correspond to the same letters in diagram 14 .

been placed in the normal facies series developed by P. Eskola and others ${ }^{2}$ ). We will therefore deal with this point at some length.

These particular parageneses must to a great extent be due to the great ability of the complex hornblende minerals to absorbe different elements isomorphically ${ }^{3}$ ). Thereby the stability of common hornblende becomes very elastic, and the $\mathrm{P}, \mathrm{T}$-conditions at which hornblende may develop will vary considerably with the mineralogical and chemical milieu in which hornblende occurs.

The hornblende (Na-free) may be considered a mixed crystal among actinolite, tremolite, and an aluminous varicty represented by point $\mathrm{b}$ in fig. 13. With reference to the $\mathrm{Al}$-free tremolite (actinolite) we know that at low temperatures (depending on the $\mathrm{Fe} / \mathrm{Mg}$ ratio) it disintegrates into tale, calcite and quartz:

1) See 1R. T. Prid r.r: Geol, Mag. Vol. LXXXII, 4, 1945, pp. 145-172.

2) P. Eskola, op. cit.

3) H. Ramberg: N. G. T. No. 2/4, 1944, pp. 42-74. 


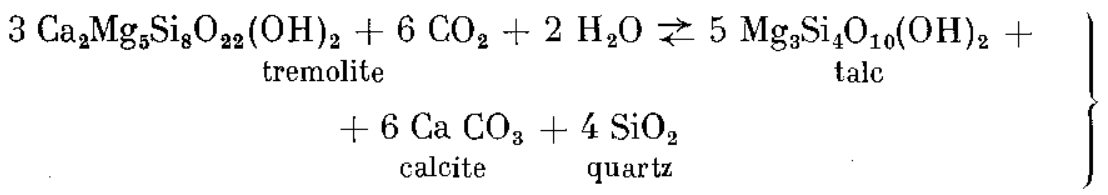

Higher temperatures make the tremolite disintegrate into diopside and rhombic hornblende (or cummingtonite) which in its turn by elevating temperature transforms into bronzite ${ }^{1}$ ).

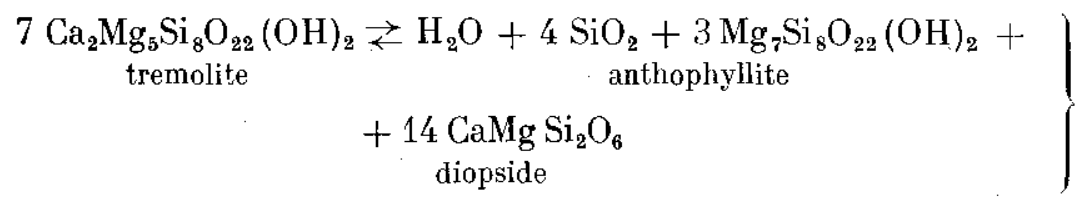

These points or lines of transition depend on the composition of the isomorphic minerals, and on the $\mathrm{H}_{2} \mathrm{O}$-tension.

The tremolite, actinolite molecule is now able to absorbe $\mathrm{Al}$, etc. from the different minerals which may accompany it, e. g. augitic pyroxene, anorthite, epidote, cordierite, (spinel at Si-deficiency), garnet, biotite, clorite, bronzite, anthophyllite, gedrite, olivine or other minerals situated at the different places in an A, C, F-diagram. These mineralswhich of course do not occur at the same time in a hornblende paragenesis -are in diffusion equilibrium with hornblendes of varying composition according to the existing minerals and the $\mathrm{P}, \mathrm{T}$-relations present.

With reference to parageneses and hornblendes containing the components $\mathrm{CaO}, \mathrm{Al}_{2} \mathrm{O}_{3}, \mathrm{SiO}_{2}, \mathrm{MgO}(\mathrm{FeO})$, and $\mathrm{H}_{2} \mathrm{O}$ it is possible to evalute an equilibrium diagram based on empirical data from metamorphic rocks, and on theoretical considerations. The absissa of diagram fig. 14 equals to the line trem. - $\mathrm{f}$ in the $\mathrm{Al}_{2} \mathrm{O}_{3}-\mathrm{CaO}-(\mathrm{Mg}, \mathrm{Fe} \cdot$, $\mathrm{Fe} \cdot$.$) O-diagram fig. 13$, and the ordinate represents increasing metamorphic facies. It is the upper parts of the diagram that are of importance for our task.

The composition represented by the left vertical line in the diagram corresponds to tremolite with excess of $\mathrm{CO}_{2}$ and $\mathrm{H}_{2} \mathrm{O}$ (in order to form calcite and talc at low temperature). The composition at a certain point in the right side of the diagram, e. g. point $\mathrm{k}$, has not, however, been definitely determined. It is here possible to change the $\mathrm{SiO}_{2}$-contents, and such a variation will displace the boundaries of the hornblende field. $\mathrm{SiO}_{2}$-poor parageneses (with spinel, olivine etc.) give rise to an upward displacement of the hornblende field boundaries, while excess of $\mathrm{SiO}_{2}$ will depress the boundaries (see p. 27 and equations $3,4,5,6,7,8$ ).

1) H, RAMBERG: N. G. T. No. 23, 1943, pp. 85 and 105. 


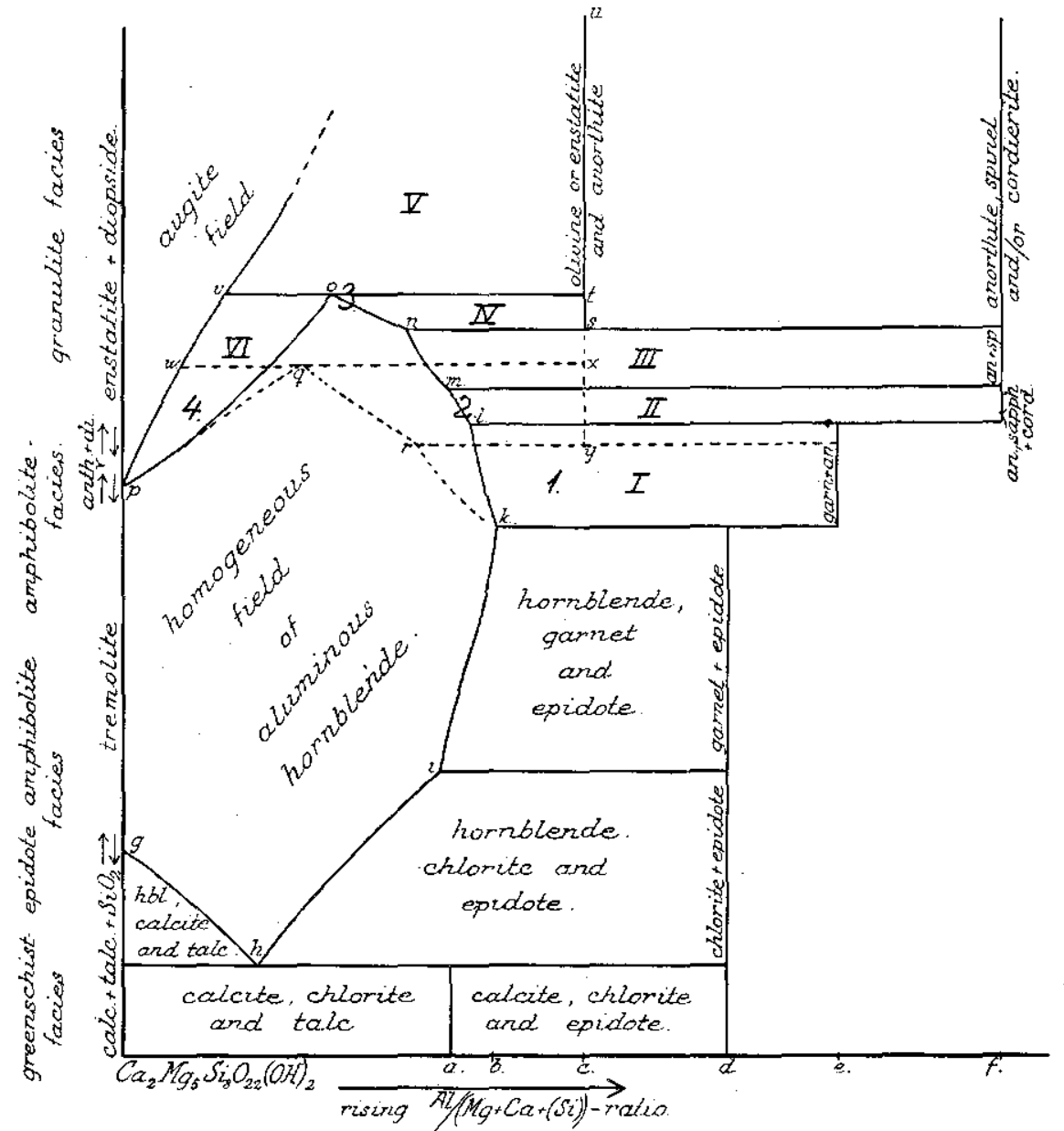

Fig. 14. liquilibriurn diagram of common aluminous hormblende. The diagram is based on petrographic observations in combination with theoretical computations. The principal feature of the diagram is supposed to be right, though, however, the points and lines may be more or less displaced relatively to the true ones. (Sce the text . The solid curves: $k, l, m, n, o, p$, on the top of the diagram correspond to parageneses undersaturatet in silica, i. e. parageneses containing olivine, spinel, corundum etc. The stippled curves hero: $p, q, r$, represent suturated or quartz-bearing paragneses. Those of the lields along the top of the hornbIende field which are marked with Ariabian numbers correspond to saturated or oversaturated rokes, while the boundaryfields marked by Roman numbers correspond to undersaturated parageneses. With reference to the lower parts of the diagram which is of no interest for our task, no distinction between saturated and undersaturated parageneses is visualized.

In the different fields bounding against the homogeneous hornblendefield a certain type of hornblende (indicated by the boundary curve) is in equilibrium with cerlain other minerals, viz.: 1: homblende, garnet, and anorthite (spinel, kyanite etc.). II : hornblende, anorthite, cordierite, spinel, sapphirine (garnet). III: hornblende, anorthite, spinel, hypersthene. IV: hornblendo, anorthite, olivine. V: olivine, augite, anorthite (hypersthene). VI: hornblende, augite, hypersthene or anthophyllite. In the augite field we have: diopsidic augite, hypersthene or anthophyllite. 1 : hornblende, gamet, and/or cordicrite, anorthite (quartz). 2 : hornblende, hypersthen, anorthite. 3: hypersthere, angite, anorthite. 4: hornblende, augite, hypersthene.

(Soe the text, pp. 23-27, and equations 3, 4, 5, 6, 7, 8, 9). 
I have therefore drawn the boundaries at both $\mathrm{SiO}_{2}$-excess (quartz), and at $\mathrm{SiO}_{2}$-deficiency (olivine, spinel) as stippled and solid curves respectively.

Supposing at first that we have olivine and anorthite along the line $s-u$ in diagram 14. At point $s$ these two minerals interact in the following manner:

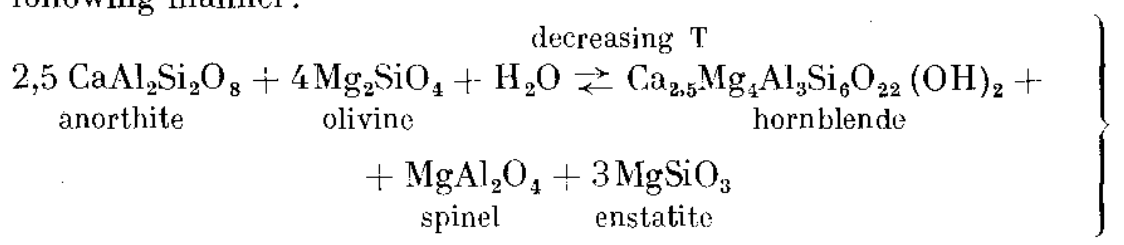

and the newly formed hornblende gets more aluminous by decreasing temperature following curve $n-m$. At point $m$ bronzite, anorthite, and spinel may for instance interact in the following way:

$$
\begin{aligned}
& 5 \mathrm{CaAl}_{2} \mathrm{Si}_{2} \mathrm{O}_{8}+10 \mathrm{MgSiO}_{3}+6 \mathrm{MgNl}_{2} \mathrm{O}_{4} \rightleftarrows 2 \mathrm{Ca}_{2,5} \mathrm{Mg}_{4} \mathrm{Al}_{3} \mathrm{Si}_{6} \mathrm{O}_{22}(\mathrm{OH})_{2}+ \\
& \text { anorthite enstatite spinel hornblendo } \\
& -\underset{\text { cordierite }}{-\mathrm{Mg}_{2} \mathrm{Al}_{4} \mathrm{Si}_{5} \mathrm{O}_{18}}+\underset{\text { sapphirine }}{3 \mathrm{Mg}_{2} \mathrm{Al}_{4} \mathrm{SiO}_{10}}
\end{aligned}
$$

(It is of course also possible that different minerals develop, e. g. kyanite ${ }^{1}$ ) or garnet, etc. In order to simplify the reactions represented by the equations above I have given the hornblende a too high content of Ca. 'Thereby the sodium necessary to balance the negative charge in these Al-rich, Si-poor hornblendes is disregarded.)

With decreasing temparature the hornblende changes along the curve $m-l$.

At point $l$ bronzite transforms into orthorhombic hornblende or cummingtonite, and from this point off the orthorhombic hornblende interacts with plagioclase in a similar manner as did bronzite at higher temperature.

Point $k$ represents the transition: anorthite $\rightleftarrows$ epidote. The reactions farther down in the diagram are of no interest for our task.

In the field $\mathrm{V}$ olivine, anorthite, and augite are present. With decreasing temperature these minerals interact in accordance with the following equations:

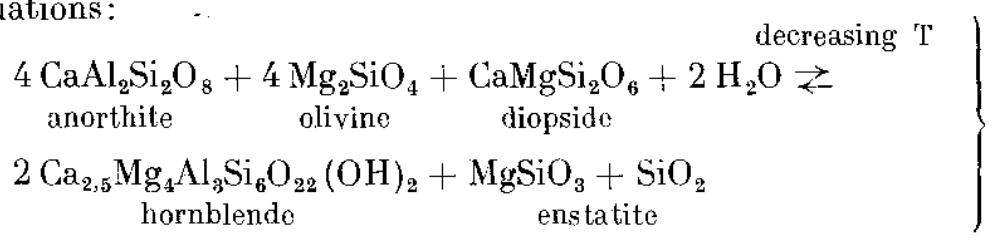

(If the diopside is sufficiently aluminous no quartz will appear.)

1) S. Fosli: X. G. T. No. 25, 1945, p. 94, and C. E. Thluey: Min. Mag. Vol. 24, $1935-37$, p. 555 . 
or:

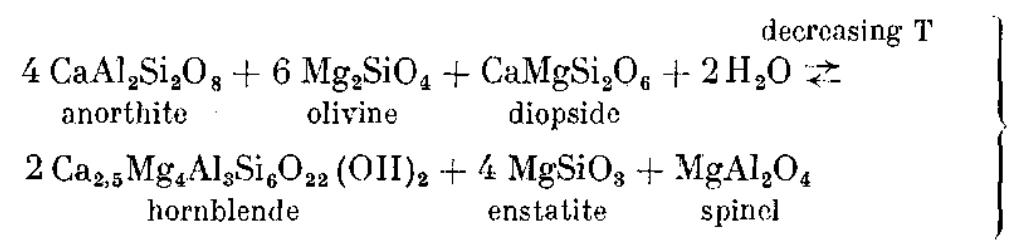

showing that spinel develops if the paragenesis is rich in olivine.

Supposing now that line $u--s$ represent a $\mathrm{SiO}_{2}$-saturated paragenesis i. e. hypersthene or enstatite, and anorthite. Then the following interactions may take place by decreasing temperature:

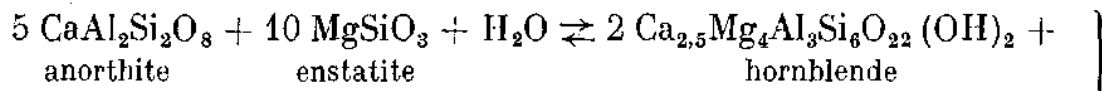

$$
\begin{aligned}
& +\mathrm{Mg}_{2} \mathrm{Al}_{4} \mathrm{Si}_{5} \mathrm{O}_{18}+3 \mathrm{SiO}_{2} \\
& \text { cordierite quartz }
\end{aligned}
$$

Garnet may also develop (probably at somewhat lower temperature, and at greater $\mathrm{Fe} / \mathrm{Mg}$ ratio):

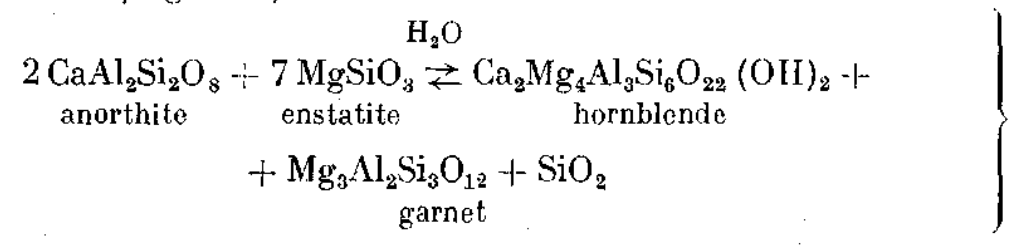

If situated in the field 3 (saturated on $\mathrm{SiO}_{2}$ ) bronzite, anorthite, and augite are present. Decreasing tomperature gives birth to the following process: (S. FosLi, op. eit.)

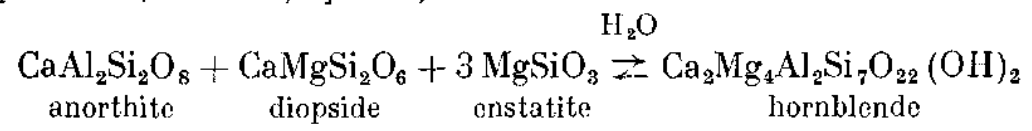

It is a fact that the interactions between bronzite and anorthite in accordance with equations 7 and 8 , or the reaction between bronzite, anorthite, and augite in accordance with equation 9 takes place by lower degree of metamorphism (lower temperatures) than these interactions in which olivine takes part.

It is a common phenomenon in the West Greenland gneisses that quartz free amphibolites develop endogenous roaction margin where hornblende (and garnet or biotite) interact forming hypersthene and anorthite. This interaction is obviously due to conveyance of $\mathrm{Si}$ and sodium from the surrounding granodioritic gneiss (p. 31). We have 
drawn attention to the similar reaction along the small quartz veins penetrating the hornblende rocks (p. 14). Thus the hornblende which is stable at comparatively high degree of metamorphism in silica-poor rocks becomes instable at excess of $\mathrm{SiO}_{2}$. Since aluminous hornblendes necessarily are poor in $\mathrm{Si}$ one may also conclude theoretically that deficiency in $\mathrm{SiO}_{2}$ establishes hornblende at higher temperatures than usual.

The diagram fig. 14 does of course not comprise all the stability conditions of hornblende, and some completing points may be added:

(1) Changing $\mathrm{Fe} / \mathrm{Mg}$ ratio will to some extent displace the hornblendefield's boundaries.

(2) If the parageneses contain sodium, plagioclase is formed, and this plagioclase will obviously possess a less $\mathrm{Ca}$ - and $\mathrm{Al}$-vapor tension than the pure anorthite so that the reactions 3-9 are displaced towards the olivine or bronzite side. Accordingly increasing amounts of sodium depress the upper parts of the hornblende field in fig. 14. On the other hand sodium is able to enter the lattice of hornblende in this way expanding the hornblende field to some extent.

(3) Presence of potassium and thus appearence of biotite will probably narrow the top part of the hormblende field in fig. 14 .

The reason for the common occurrence of aluminous hornblende in the Sukkertoppen sapphirine-bearing complex at those high temperatures which obviously were present here, seems to be:

(a) Si-poor milieu (the occurrence of spinel and olivine),

(b) Na-poor, Ca-rich milieu (the plagioclase is bytownitic), and

(c) Small concentrations of potassiurn (rarely phlogopite).

In such circumstances it appears that common aluminous metamorphic hornblende is established up to the lower parts of the granulite facies where in siliceous rocks hornblende breaks up into hypersthene, anorthite (and diopside).

\section{Genesis of the sapphirine-bearing complex.}

It is not probable that the basic inclusion dealt with here has received "basic" elements (Ca, Mg, etc.) from the enclosing rocks with which the inclusion has undergone metamorphic and metasomatic interactions. The surrounding gneisses are themselves poor in $\mathrm{Ca}, \mathrm{Mg}$, $\mathrm{Fe}$, etc. and could therefore hardly have functioned as the source of these elements. It seems more probable that the sapphirine-bearing complex was originally of very basic affinity, and that the exchange of matter which may have taken place between the inclusion and the gneiss has 
displaced "basic" elements from the inclusions towards the gneiss, and "acid" elements ( $\mathrm{Si}, \mathrm{K}, \mathrm{Na}, \mathrm{Nl}$ ) into the inclusion.

The included complex may originally have been:

(1) Calcareous or dolomitic sediments,

(2) Ultrabasic magmatic roeks.

The mineral assemblage of the present metamorphosed product impeaches the hypothesis: calcite-dolomite sediments. At numerous other localities along the coast of West Greenland such sediments are altered into ordinary skarn rocks with the characteristic minerals: diopside, titanite, scapolite, apatite, etc. As a rule the skarn occurrences also contain remnants of unaltered calcite.

Alternative 2 is very probable. Rocks such as peridotites, dunites, troctolites, allivalites, etc. will transform into spinel-bearing hornblendites at the metamorphic degree which corresponds to the Sukkertoppen occurrence. Even nowadays parts of the complex are peridotitic.

At other localities in this large field, e. g. Søndre Strømfiord, we find ultrabasites altered into low-metamorphic soap-stones. At Qeqertalik south of Holsteinsborg lenses of ultrabasites carrying hornblende, lyppersthene, spinel, olivine, etc. are encountered. The numerous remnants of hypersthene-bearing xenolithes in the Sukkertoppen gneiss may also most reasonable represent altered ultrabasic magmatic rocks. The comparatively large lense of dunite at Siorarsuit should also be remembered $^{1}$ ).

The alteration of the sapphirine-bearing amphibolite into hypersthene, diopside, plagioclase, and biotite along the margin of small quartz veins (p. 14) indicates that the primary rock contained some diopside or augite. In the Si-poor milieu of the olivine-bearing ultrabasite olivine, anorthite and diopsidic augite interacted under the formation of hornblende and spinel in accordance with equation (6) p. 26 . A conveyance of $\mathrm{SiO}_{2}$, however, drives the reaction backwards along some other ways:

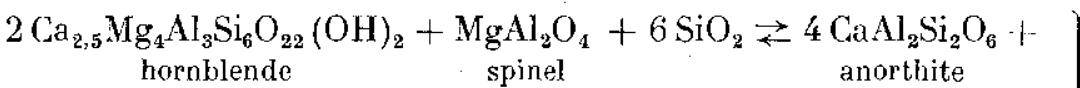

$$
\begin{aligned}
& +\underset{\text { diopside }}{\mathrm{CaMgSi}_{2} \mathrm{O}_{6}} \div \underset{\text { enstatite }}{8 \mathrm{MgSiO}_{3}}+2 \mathrm{H}_{2} \mathrm{O}
\end{aligned}
$$

Therefore the diopside is regenerated along the narrow quartz veins. If we do not postulate a considerable conveyance of substances from the surroundings we may conclude that the original ultrabasite was of

1) K. Rordam: Medd. o. Grønl. Vol 8, 1889, p. 129, and A. Noe-Nygand: Medd. D. G. F. Vol, 10, 1945, p. 651. 
troctolitic character containing the following minerals: plagioclase, olivine, some hypersthene and diopsidic augite.

This troctolitic inclusion has undergone certain chemical and mechanical reactions along with the enclosing gneiss during the dynamothermal metamorphism. Firstly the high temperature paragenesis of the basic rock transforms into an assemblage being stable at the lower temperatures characterizing the dynamothermal metamorphism. Thereafter the inclusion has been subjected to a certain metamorphic differentiation whereby the different minerals tend to gather into certain segregations. Furthermore some exchange of matter between the inclusion and the country rocks took place. The comparatively rigid ultrabasite has also undergone rupture to a small extent during the mechanical deformations thus giving rise to consolidation of quartz and pegmatite veins in the fissures. In this connection it should be remembered that the hypersthene and mica of the pegmatite are richer in iron (p. 15) than the same minerals of the rocks traversed by the veins. Furthermore one should remember that the pegmatitic plagioclase is more acid than the bytownite of the inclusion. These facts harmonize with the assumption that the veins are formed during metamorphic differentiation under which one has to assume that $\mathrm{Na}$ and $\mathrm{Fe}$ diffuse more rapidly than do $\mathrm{Ca}$ and $\mathrm{Mg}$.

The high temperature paragenesis olivine-plagioclase (diopside) gives birth to common hornblende, spinel and hypersthene at decreasing temperature in accordance with equation 3 p. 25 . (This is the typical reaction in metamorphic olivine-gabbros where a corona of hypersthene, hornblende, and spinel is formed between plagioclase and olivine. Such reactions are common in the so-called hyperites of the Norwegian and Swedish pre-Cambrian areas ${ }^{1}$ ). But in our case the corona reaction comprises the total rock complex.

The above-mentioned reactions represented by equations 3 and 6 p. 25 have obviously led to complete equilibrium since plagioclase and olivine are never found together. Plagioclase (hornblende)-bearing rock varieties are most common in the complex, olivine-bearing types are rare, indicating that the original rock was very rich in plagioclase. At places of great concentration of olivine there were deficiency of plagioclase so that olivine now exists alongside with hornblende and spinel.

At the $\mathrm{P}, \mathrm{T}$-conditions present during the metamorphism a rather intense metamorphic differentiation took place during which headsize spinel porphyroblasts were formed and the complex was heterogenized in different ways. This metamorphic differentiation was a process that took place by help of migration of substances in the form of ions, atoms

1) W. C. Brøggen: Vid. Selsk. Skr. I Mat. Nat. KI. No. 1, 1934, and P. H. Lundegirdh: Bull. Geol. Inst. Ujppsala Vol. XXIX 1943, pp. 305-388. 
and molecules from places of high chemical activity to places of low chemical activity ${ }^{1}$ ).

After the low temperature sides of equations 3 and 6 p. $525-26$ wore established in the course of the regressive metamorphism of the ultrabasite other reactions and processes have taken place. In particular the formation of sapphirine on the cost of spinel shows that the processes were not finished by the reaction between olivine and plagioclase (equations 3 and 6). The sapphirinization and the phlogopitization developed in the spinel-rich parts of the complex may be considered the finishing processes during the metamorphism and metasomatism.

Sapphirine and phlogopite may ejther have developed on account of interactions between the present minerals due to decreasing temperature below the reaction points of equations 3 and 6 , or they may represent a weak $\mathrm{Si}$ and $\mathrm{K}$ metasomatism with conveyance of this element from the country rocks.

A moderate decrement of temperature as compared with the interaction point of equations 3 and 6 gives reasonable rise to a reaction of the following type:

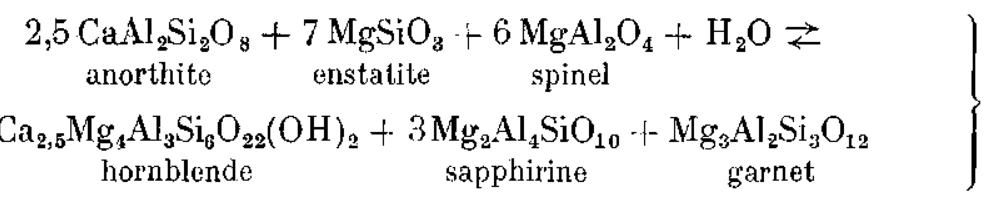

The reaction may also have taken place in accordance with equation (4) p. 25.

However, since we do not find garnet in the sapphirine-bearing rocks it is logical to assume that small amounts of potassium being camouflaged in the mixed crystals, e. g. plagioclase or hornblende, take part in the reactions under the formation of phlogopite:

$$
\begin{aligned}
& 2,5 \mathrm{CaAl}_{2} \mathrm{Si}_{2} \mathrm{O}_{8}+10 \mathrm{MgSiO}_{3}+6 \mathrm{MgAl}_{2} \mathrm{O}_{4}+3 \mathrm{H}_{2} \mathrm{O}+\mathrm{K}_{2} \mathrm{O} \rightleftarrows \\
& \text { anorthite enstatite spinel }
\end{aligned}
$$

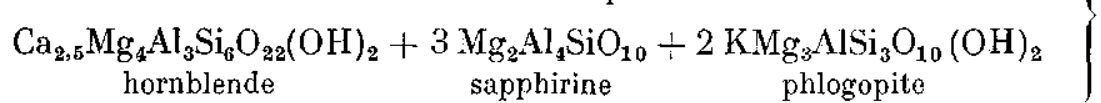

In this connection it is important to remember that the rock contains but small amounts of both sapphirine and phlogopite.

The paragenesis of the rock shows that the forward reaction of equation 12 is not complete. Quenching of the reaction and thereby involved instability may account for the incomplete reaction. But on the other hand the paragenesis may also represent true equilibrium. The simultaneous existence of 6 minerals: plagioclase, enstatite, spinel, horn-

1) H. Ramberg: N. G. T. No. 24, 1944, pp. 98-111. 
blende, sapphirine, and phlogopite may in this case be explained by deficiency in $\mathrm{K}_{2} \mathrm{O}$, by incomplete isomorphous exchange of $\mathrm{Mg}$ and $\mathrm{Fe}$ in the ferromagnesian minerals, or by the small percentage of $\mathrm{Na}$ in the plagioclase.

Since the $\mathrm{Mg} / \mathrm{Fe}$ ratio in sapphirine is greater than in the spinel of which the sapphirine is formed (p.16), the Mg-component of the spinel will be leached away of this mineral during the sapphirinization so that stability may be attained when the spinel has become somewhat enriched in $\mathrm{Fe}$. In a similar manner one finds that the anorthite-component is leached out of the plagioclase in the course of reaction probably establishing a plagioclase of certain composition in equilibrium with the other minerals.

However, it is also possible that the sapphirinization and phlogopitization are due to a small supply of $K$ and Si from the adjacent granodioritic gneiss:

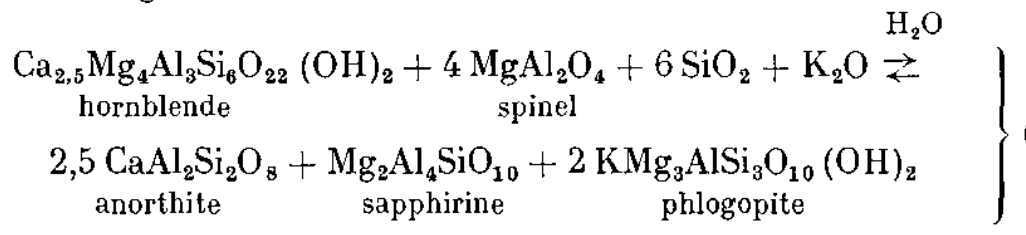

While in the previous reaction (12) hornblende was formed on the cost of plagioclase, in the reaction above plagioclase appears at the cost of hornblende

The occurrence of a plagioclase-phlogopite mantle around the sapphirinizated spinel porphyroblast situated in the hornblende rocks, is indicative of the correctness of the latter process. On the other hand the large amounts of unaltered spinel and the low average contents of phlogopite in the complex speak against an intense conveyance of salic substance. One may of course also consider the migration of matter an entirely internal process, $\mathrm{i}$. e. the $\mathrm{Si}$ and $\mathrm{K}$ amounts necessary for the sapphirinization and phlogopitization have migrated inside the complex according to the laws of metamorphic differentiation.

However, whether the sapphirinization takes place becauce of interaction between minerals lying intimately intermingled, or it appears by help of conveyance of $\mathrm{Si}$ and $\mathrm{K}$ towards the spinel-rich parts of the complex, i. e. by interaction between minerals lying farther distances apart, is of no essential importance. In both cases the appearence of sapphirine is due to a small decrease of temperature below the reaction point of equations 4, 11, 12, and 13 pp. 25, 30, 31 thus placing the upper stability boundary of sapphirine at these temperatures, i. e. in the lower parts of the granulite facies. 


\section{SUMMARY}

A sapphirine-bearing complex is situated as a large inclusion in the Sukkertoppen granodioritic gneiss some $3-4 \mathrm{~km}$ north of the Sukkertoppen colony. The complex has, during the orogeny, undergone mechanical and chemical metamorphism together with the enclosing gneiss. Thereby the minerals of the troctolitic inclusion have been subjected to transitions which have developed hornblende, bronzite, and spinel on the cost of olivine and plagioclase. All the olivine is commonly altered, while bytownitic plagioclase exists in excess. In schlieren with primarily great concentration of olivine the plagioclase is completely altered giving rise to olivine and bronzite-rocks with smaller amounts of hornblende and spinel.

As the last reaction prior to the quenching of the rock before this was elevated too high during the erosian of the crust, some of the minerals interacted during the formation of sapphirine and phlogopite. Porhaps this process was combined with a small conveyance of $\mathrm{Si}$ and $\mathrm{K}$ from the surrounding gneiss.

During the whole alteration the complex was subjected to a certain metamorphic differentiation with migration of elements inside the complex so that great porphyroblasts of spinel, and different bands and schlieren appeared. The mechanical deformation was essentially a plastic one, rupture is rarely found. But where fissures are encountered these are filled with quartz along which the Si-metasomatism has been comparatively intense altering the hornblende-spinel rocks into hypersthene, plagioclase, and diopside.

Mineralogisk Museum.

København, Januar 1947. 